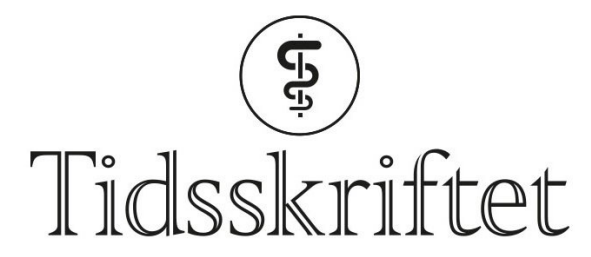

DEN NORSKE LEGEFORENING

\title{
Kan aldersbetinget muskeltap hemmes med legemidler?
}

FRA ANDRE TIDSSKRIFTER

HAAKON B. BENESTAD

Universitetet i Oslo

Muskelpeptidet apelin virker anabolt på muskelcellene i mus, men produksjonen avtar med alderen.

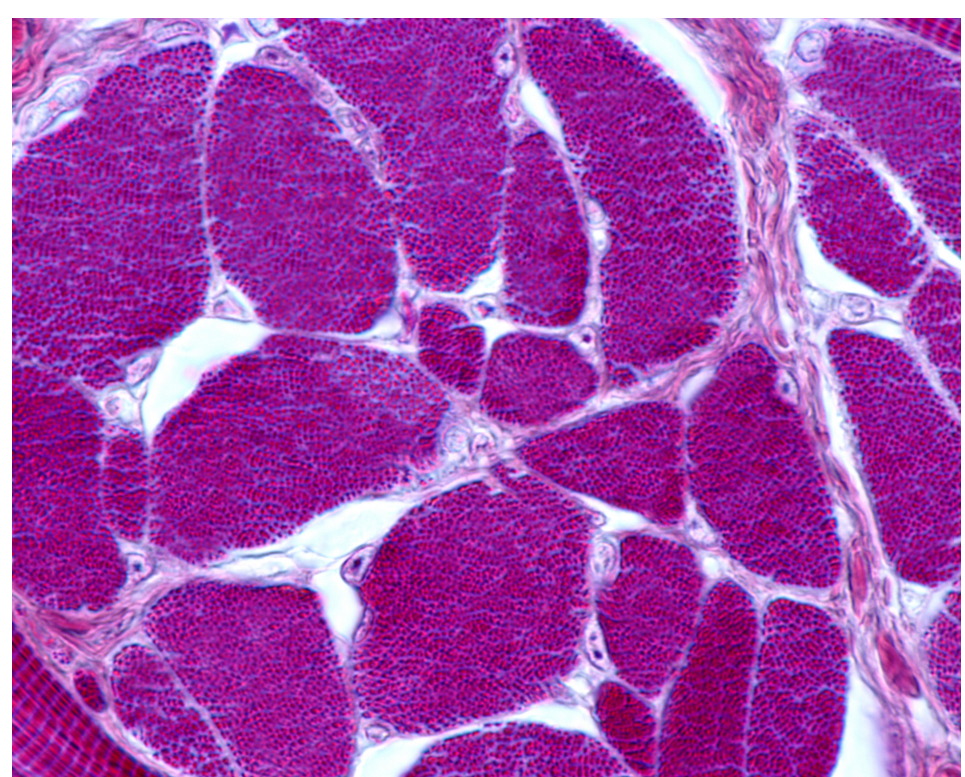

Tverrstripet skjelettmuskulatur, myofibriller. Illustrasjonsfoto: Jose Luis Calvo Martin \& Jose Enrique Garcia-Mauriño Muzquiz/iStock.

Degenerativt alderstap av muskelmasse, sarkopeni, kan bety mye for hvordan gamle mennesker klarer seg i hverdagen. I en ny studie fikk mus uten myokinet apelin eller dets reseptor i muskelvev en dramatisk svekkelse av muskelfunksjonen ved aldring (1).

I studien var apelinsignaleringen i muskelcellene blitt genetisk manipulert. Ekstra apelingener i muskelcellene økte produksjonen av apelin, mens atrofiering av musklene som følge av påtvungen inaktivitet, reduserte produksjonen. Med $ø \mathrm{kt}$ apelinmengde $\emptyset \mathrm{kte}$ antall mitokondrier, mitokondriene ble normalisert, og veksten av muskelcellene og den regenerative kapasiteten til musklenes stamceller etter muskelskade økte.

Muskelcellenes evne til autofagi (celleforyngelse) ble bedret og inflammasjon i gamle muskler dempet. Det var en positiv tilbakekobling mellom apelinproduksjon i muskelcellene (og plasmanivå av apelin) og muskelstyrke og utholdenhet. Et lignende 
forhold ble funnet hos eldre fors $ø$ kspersoner. Hos mus som fikk daglig behandling med apelin intraperitonealt, ble den aldersbetingede muskelsvakheten reversert. Det ble også påvist nedstrøms signalmekanismer for stimulering av apelinreseptoren.

Forskerne bak studien mener at måling av apelinnivå i plasma kan bli en biomarkør for responsen på trening hos eldre personer og at apelin kan tenkes å bli et terapeutisk supplement til eldre som ikke kan trene nok, spesielt hvis en peroral apelinreseptoragonist med lang virketid kunne designes.

- Dette er en spennende studie med interessante funn, sier Jo C. Bruusgaard, fysiolog og professor ved Høyskolen Kristiania. - Denne studien bidrar til å forstå mekanismene i sarkopeniprosessen, og viser at apelin, som er et sirkulerende protein, kan tenkes å bli utnyttet i terapeutisk sammenheng.

\section{LITTERATUR:}

1. Vinel C, Lukjanenko L, Batut A et al. The exerkine apelin reverses age-associated sarcopenia. Nat Med 2018; 24:1360 - 71. [PubMed][CrossRef]

Publisert: 23. oktober 2018. Tidsskr Nor Legeforen. DOI: 10.4045/tidsskr.18.0725

(C) Tidsskrift for Den norske legeforening 2020. Lastet ned fra tidsskriftet.no 